\title{
Kinetic and ecotoxicological evaluation of the direct orange 26 dye degradation by Fenton and solar photo-Fenton processes
}

\author{
Avaliação cinética e ecotoxicológica da degradação do corante têxtil direct orange 26 \\ por processos Fenton e foto-Fenton/solar
}

Rayany Magali da Rocha Santana ${ }^{1}$, Graziele Elisandra do Nascimento ${ }^{1}$, Polyana Karynne de Aguiar Silva ${ }^{1}$, Alex Leandro Andrade de Lucena ${ }^{1}$, Thamara Figueiredo Procópio ${ }^{2}$, Thiago Henrique Napoleão르 ${ }^{2}$ Marta Maria Menezes Bezerra Duarte ${ }^{1}$, Daniella Carla Napoleão ${ }^{1}$

\author{
${ }^{1}$ Departamento de Engenharia Química, Universidade Federal de Pernambuco, PE, Brasil \\ rayanymagalirocha@gmail.com; grazielen@yahoo.com.br; polyana.karynne@hotmail.com; lucenaalex3@gmail.com; mmmbduarte@gmail.com; \\ danicarlan@gmail.com \\ 2 Departamento de Bioquímica, Universidade Federal de Pernambuco, PE, Brasil \\ thamarafp@yahoo.com.br; thiagohn86@yahoo.com.br
}

\begin{abstract}
The presence of color in textile effluents has been studied because of the need for more effective treatments. Therefore, advanced oxidative processes $(A O P)$ have been used in the degradation of dyes, as well as in the conversion of organic matter. This study evaluated the degradation of the direct orange 26 textile dye by Fenton and photo-Fenton processes (with natural solar radiation). A statistical analysis, based on factorial $2^{3}$ indicated the best working conditions, being: $\left[\mathrm{H}_{2} \mathrm{O}_{2}\right]=100 \mathrm{mg} \cdot \mathrm{L}^{-1}$ and $\mathrm{pH} 3-4$, for both AOP in that the $[\mathrm{Fe}]=1 \mathrm{e} 5 \mathrm{mg} \cdot \mathrm{L}^{-1}$, for photo-Fenton and Fenton, respectively. The results of the kinetic studies demonstrated a good fit to the nonlinear kinetic model proposed by Chan and Chu, with values of $R^{2}>0,996$ (photo-fenton) and $R^{2}>0,939$ (Fenton). The tests performed to evaluate the chemical oxygen demand indicated conversions of $62.05 \%$ (Fenton) and $66.41 \%$ (photo-Fenton). Finally, the ecotoxicity study indicated that the post-treatment samples were non-toxic to the bacteria Escherichia coli and Proteus mirabilis but showed growth inhibition for Lactuca sativa (Fenton and photo-Fenton) seeds and for Brassica juncea and Portulaca grandiflora (Fenton).
\end{abstract}

Keywords: Chemical oxidation. Chemical oxygen demand. Textile dyes.

\section{Resumo}

A presença de cor em efluentes têxteis tem sido alvo de estudo, devido a necessidade de tratamentos mais eficazes. Diante disso, processos oxidativos avançados (POA) têm sido utilizados na degradação de corantes, assim como na conversão da matéria orgânica. Este estudo avaliou a degradação do corante têxtil laranja direto 26 via processos Fenton e foto-Fenton (com radiação solar natural). Uma análise estatística, baseada em planejamentos fatoriais $2^{3}$ indicaram as melhores condições de trabalho, sendo elas: $\left[\mathrm{H}_{2} \mathrm{O}_{2}\right]=100 \mathrm{mg} \cdot \mathrm{L}^{-1}$ e $\mathrm{pH} 3-4$, para ambos os $P O A$ em quanto que a $[\mathrm{Fe}]=1$ e $5 \mathrm{mg} \cdot \mathrm{L}^{-1}$, para o foto-Fenton e o Fenton, respectivamente. Os resultados dos estudos cinéticos demonstraram um bom ajuste ao modelo cinético não-linear proposto por Chan e Chu apresentando $R^{2}>0,996$ (foto-Fenton) e $R^{2}>0,939$ (Fenton). Os ensaios realizados para avaliação da demanda química de oxigênio indicaram conversões de 62,05\% (Fenton) e 66,41\% (foto-Fenton). Por fim, o estudo de ecotoxicidade indicou que as amostras pós-tratamento não são tóxicas para as bactérias Escherichia coli e Proteus mirabilis, mas apresentou inibição do crescimento para sementes de Lactuca sativa (Fenton e foto-Fenton) e para Brassica juncea e Portulaca grandiflora (Fenton).

Palavras-chave: Corantes têxteis. Demanda química de oxigênio. Oxidação química. 


\section{INTRODUCTION}

The number of researches and publications on the environmental issue is increasing. Several groups of contaminants at different levels of concentrations have been studied by researches from all over the world, among them, the most cited environmental pollutants in the academic world are: pharmaceuticals (NAPOLEÃO et al, 2018; BANASCHIK et al, 2018), hormones (YONGZE et al, 2017), polycyclic aromatic hydrocarbons (HAPs) (LABIADH et al, 2015) and dyes (BILINSKA; GMUREK; LEDAKOWICZ, 2017; SANTANA et al, 2017).

Among the classes of compounds cited, the textile dyes deserves attention, especially in the Northeast of Brazil. These substances are widely used by microenterprises in that region of the country (ABIT, 2017), being easily found in aquatic matrices, since the industrial process employs large volumes of water (HASANBEIGI; HASANABADI; ABDORRAZAGHI, 2012). Another factor contributing to the identification of dyes in the environment is related to the fact that conventional treatments used in effluent treatment plants (ETS) show little efficiency in the degradation of persistent and refractory compounds such as dyes (MARTINS et al, 2011).

In this context, it is of fundamental importance that other treatments are sought that can promote complete degradation of persistent pollutants. The advanced oxidative processes (AOP) refer to a consolidated technique that has presented efficiency in the degradation of dyestuffs (BRINDHA et al, 2018), plasticizers (DÜKKANCI, 2018), phenolic compounds (HERNÁNDEZ-FRANCISCO, PERAL, BLANCO-JEREZ, 2017). The AOP act through a series of chemical reactions mediated by hydroxyl radicals. These, in turn, come from a strong oxidizing agent, usually hydrogen peroxide $\left(\mathrm{H}_{2} \mathrm{O}_{2}\right)$. Then it is possible to divide the oxidation process into two systems: 1) Those involving homogeneous reactions, such as $\mathrm{UV} / \mathrm{H}_{2} \mathrm{O}_{2}$, Fenton and photo-Fenton; and 2) those that comprise heterogeneous reactions (photocatalytic processes), assisted not by radiation (NAGEL-HASSEMER et al, 2012; CHAKMA; DAS; MOHOLKAR, 2015).

Among the different AOP, studies have been carried out on the type of radiation to be used in the processes that make use of it. One of the most widely used types is the radiation emitted by ultraviolet light, which can be produced through light bulbs (QUEIROZ et al, 2011). However, at industrial level its use is not very feasible due to its high energy expenditure. Thus, for an industrial application and a low cost, the use of ultraviolet radiation originating from sunlight has been analyzed (TIBURTIUS, 2008). When comparing the use of artificial irradiation with natural, Nogueira and Modé (2002), as well as Trovó; Villa and Nogueira (2005) reported similar results for the two types of radiation studied in relation to the decontamination of effluents containing phenols and herbicides. Both studies were able to degrade the contaminants in values higher than 95\%. Similarly, Santana et al (2017) achieved a degradation of a solution containing the mixture of Reactive blue BF-5G and Remazol red RB 133\% color dyes of $86.63 \%$ for the photo-Fenton/solar process and $87.02 \%$ for the photo-Fenton/sunlight.

When using natural solar radiation, it is important to note that different regions will exhibit different spectral behaviors. This fact is related to the electromagnetic radiation of the sun, that when undergoing some attenuations does not reach the earth's surface integrally, but still has contributions in the ultraviolet, infrared (IV) and visible bands. A factor that contributes to these attenuations is related to the absorption effect of the gases present in the atmosphere. Figure 1 shows the behavior of the electromagnetic spectrum of solar radiation, as well as of carbon dioxide, water vapor and ozone (PEREIRA et al, 2017). 
Figure 1- Electromagnetic spectrum of solar radiation

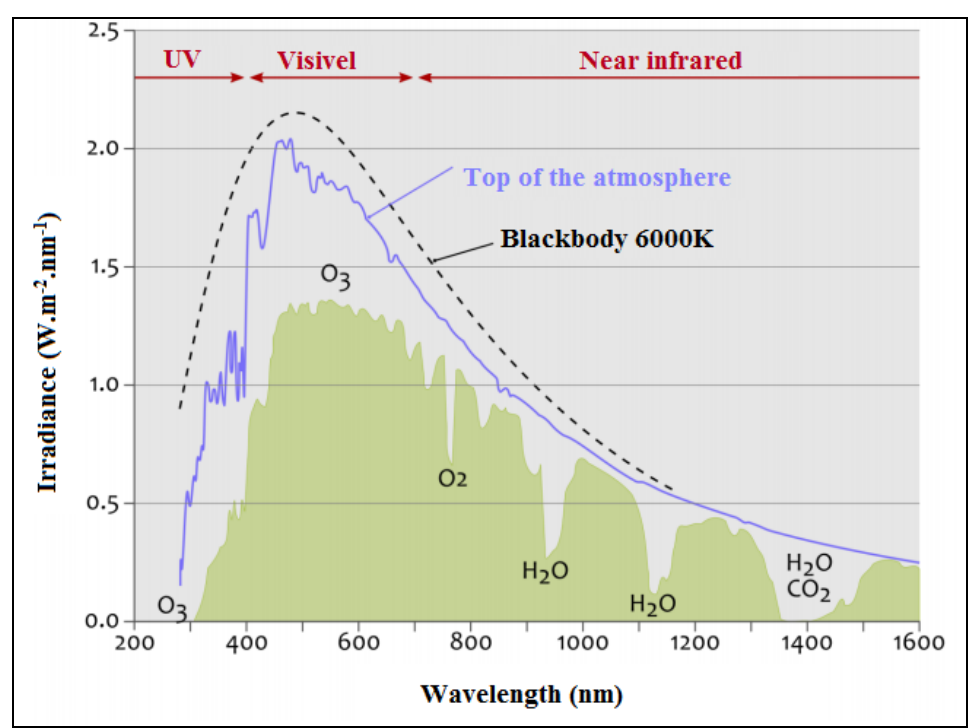

Source: Adapted from Pereira et al, 2017

According to the same authors, carbon dioxide and oxygen absorb significantly in the infrared (IV) region, as well as the water vapor that besides absorbing in the IV, in suspension form is a strong absorber of the solar region, its interference in several bands of the spectrum can be seen through Figure 1. Ozone, on the other hand, absorbs part of the solar radiation in the ultraviolet region, acting to avoid that some of the rays emitted in this range reach the Earth's surface.

Different types of behavior can be observed regarding the solar irradiation in Brazil, since the country has a vast territorial extension. In Brazilian northwest there is the highest solar potential in the country, presenting an average value of $5.49 \mathrm{kWh} . \mathrm{m}^{-2}$ of global irradiation. Similar average values are observed for the southeast $\left(5.26 \mathrm{kWh} . \mathrm{m}^{-2}\right)$ and center-west $\left(5.20 \mathrm{kWh} . \mathrm{m}^{-2}\right)$ regions of Brazil. This is an indication that in these 3 regions the use of solar radiation for AOP treatments can be done with good potency (PEREIRA et al, 2017).

Due to the processes that have a good efficiency in the degradation of persistent pollutants, a concern arises as to the formation of the reactional by-products, which can sometimes present a higher toxicity than the original compounds (SALVADOR; MARCOLINO JÚNIOR; PERALTA-ZAMORA, 2012). Thus, in addition to physicochemical analyzes, the efficiency of the degradation process can also be evaluated through ecotoxicological tests, through bioindicators (ZAGATO, BERTOLETTI, 2006; NAPOLEÃO et al, 2018). In these trials, the influence of substances on the development of representative biota species is studied. It is recommended that in this evaluation more than one trophic level be covered, because of the different manifestations that organisms of different species may present against contaminants (PUNZI et al, 2015). Escher et al (2011) state that it is possible to carry out such tests using microorganisms, plants, algae, invertebrates and fish.

In view of the above, the present work has the o objective of evaluating the degradation of the direct orange 26 dye (DO26) from the Fenton and photo-Fenton processes, determining the best reaction conditions through experimental planning. In addition, it also aims to analyze the kinetics of degradation and the toxicity of the waste generated after the treatment processes. 


\section{MATERIAL AND METHODS}

\subsection{Dye solution, analytical method}

For the degradation tests a working solution containing the direct orange dye 26 (DO26) (Table 1) was prepared in a concentration of $50 \mathrm{mg} \cdot \mathrm{L}^{-1}$. Then, based on a previous spectral scanning analysis on visible ultraviolet spectrophotometry equipment (UV/Vis) (Thermoscientific) the analytical curves were obtained for each of the wavelengths $(\lambda)$ characteristic of the dye under study, being: 495, $304 \mathrm{e}$ $238 \mathrm{~nm}$. The determination of the dye concentration before and after the treatment was performed using a linear and precise method, whose parameters meet the requirement of INMETRO (2011).

Table 1 - Characteristics of DO26 dye (Safa and Bhatti, 2011)

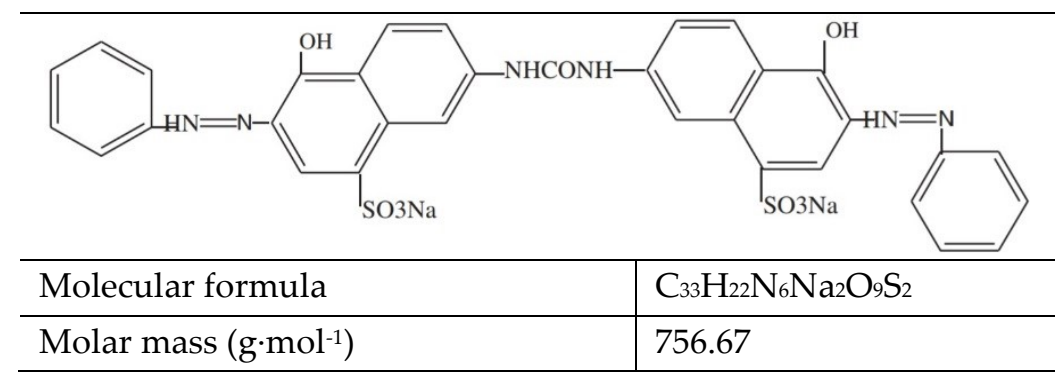

\subsection{Preliminary study: evaluation of the efficiency of advanced oxidative processes}

In order to verify the viability of the advanced oxidative processes (AOP) in the degradation of the DO26, an initial study in triplicate was carried out. For this, $50 \mathrm{~mL}$ of the working solution was submitted to degradation using two different types of processes: Fenton and photo-Fenton assisted by natural solar radiation. The period of exposure to the AOP was $60 \mathrm{~min}$, using $5 \mathrm{mg} \cdot \mathrm{L}^{-1}$ of concentration of iron ([Fe]), without $\mathrm{pH}$ adjustment. The concentration of hydrogen peroxide $\left(\left[\mathrm{H}_{2} \mathrm{O}_{2}\right]\right)$ used was 100 $\mathrm{mg} \cdot \mathrm{L}^{-1}$. This reagent was fractionally added in amounts equal to one-half of the total concentration of each assay and added at the times of 0 and 15 minutes.

\subsection{Determination of the best working condition: factorial design}

Based on the results of the preliminary study, and to obtain the best working conditions for the AOP studied, a factorial design $2^{3}$, was elaborated, with a central point in triplicate. The variables analyzed in the degradation process of the compounds were: $\left[\mathrm{H}_{2} \mathrm{O}_{2}\right],[\mathrm{Fe}]$ e $\mathrm{pH}$. The minimum, central and maximum levels studied for each factor were, respectively: $\left[\mathrm{H}_{2} \mathrm{O}_{2}\right]-100,150$ e $200 \mathrm{mg} \cdot \mathrm{L}^{-1}$; [Fe] - 1, 3 e $5 \mathrm{mg} \cdot \mathrm{L}^{-1}$ e $\mathrm{pH}-3-4,4-5$ e $5-6$.

\subsection{Kinetic evaluation of the degradation processes}

According to the best conditions obtained in the study of factorial design, tests were carried out to determine the kinetics of DO26 dye degradation through Fenton and solar photo-Fenton processes. For this purpose, $1 \mathrm{~L}$ of the working solution was irradiated and aliquots were removed at regular intervals for a period of 120 minutes. The degradation kinetics were described from the concentration 
data obtained after the treatment, which were interpreted according to the non-linear model of pseudo-first order proposed by Chan and Chu (2003), represented in Equation 1.

$$
C=C_{0} \cdot\left(1-\frac{t}{\rho+\sigma t}\right)
$$

In which, $\mathrm{C}$ is the concentration of the dye $\left(\mathrm{mg} \cdot \mathrm{L}^{-1}\right)$ after treatment at a reaction time $\mathrm{t}(\mathrm{min})$, and $\mathrm{C}_{0}$ is the initial concentration of the dye $\left(\mathrm{mg} \cdot \mathrm{L}^{-1}\right)$. The parameters $\rho$ and $\sigma$ are experimental constants that represent the reaction kinetics $(\mathrm{min})$ and the oxidative capacity of the system (dimensionless), respectively. The values of $1 / \rho$ and $1 / \sigma$ correspond to the initial kinetic constant of pseudo-first order and the maximum oxidation capacity in the different investigated conditions.

\subsection{Behavior of chemical oxygen demand}

In the best working condition, the conversion of organic matter was evaluated by means of spectrophotometric method to determine the chemical oxygen demand (COD). For this purpose, the procedure described in Method 5220D of the Standard methods for the examination of water and wastewater (APHA, 2012) was followed. The analysis was performed before and after treatment with the Fenton and photo-Fenton solar processes.

\subsection{Toxicity Study: evaluation against seeds and bacteria}

To evaluate the toxicological effects of the treatment applied to the environment, toxicity tests were carried out against lettuce (Lactuca Sativa), mustard (Brassica juncea), chicory (Cichorium intybus) and onze-hours (Portulaca grandiflora) seed, and against the bacteria Escherichia coli UFPEDA 224 and Proteus mirabilis UFPEDA 767. The seed test was based on the methodology described by Napoleão et al (2018). The solutions were evaluated before and after submission to the AOP, with the relative growth rate (RGR) and germination index (GI), according to Equations 2 and 3.

$$
\begin{aligned}
& R G R=\frac{(R L S)}{(R L C)} \\
& G I=R G R \frac{(S G S)}{(S G C)} \times 100
\end{aligned}
$$

In which, RLS is the total root length of the sample; RLC is the total root length in the negative control; SGS is the number of seeds germinated in the sample and SGC is the number of seeds germinated in the negative control.

To perform the toxicity experiments using bacteria, these were cultured on Brain Heart Infusion medium (BHI) overnight at $36^{\circ} \mathrm{C}$. Then, the colonies were then resuspended in sterile saline solution $\left(\mathrm{NaCl} 0,15 \mathrm{~mol} \cdot \mathrm{L}^{-1}\right)$ and adjusted turbidimetrically at a wavelength $(\lambda)$ of $600 \mathrm{~nm}$, being evaluated their optical densities in this $\lambda$ (DO600) to obtain suspension equivalent to $10^{6}$ colony forming units (UFC) per $\mathrm{mL}$. In these assays, the samples were filtered on sterile PVDF syringe filters (13 $\mathrm{mm} \times 0.22 \mu \mathrm{m})$. 
These samples were tested at five different concentrations, including: undiluted sample and samples diluted 1:10, 1: 100, 1: 500 and 1: 1000 in ultrapure water. The assay was performed on 96-well microtiter plates and each sample $(150 \mu \mathrm{L})$ was incubated $\left(24 \mathrm{~h}\right.$ at $\left.36^{\circ} \mathrm{C}\right)$ with the suspension of the aforementioned bacteria (17 $\mu \mathrm{L} ; 10^{6} \mathrm{UFC} / \mathrm{mL}$ in $\left.\mathrm{NaCl} 0.15 \mathrm{~mol} \cdot \mathrm{L}^{-1}\right)$ half a broth BHI $(33 \mu \mathrm{L})$. The negative control corresponded to bacterial cells treated with ultrapure water. Before and after the incubation period DO600 readings were taken to determine the percent growth compared to the negative control (100\% growth). Each assay was performed in triplicate and three independent experiments were performed.

\section{RESULTS AND DISCUSSION}

\subsection{Preliminary study: evaluation of the efficiency of advanced oxidative processes}

Initially, a spectral scan (200 to $600 \mathrm{~nm}$ ) was performed to detect the wavelengths at which degradation of the dye under study would be monitored. Figure 1 shows the spectra of the molar absorptivity for direct orange 26 dye (DO26).

Figure 2 - Scanning spectrum for DO26 solution $\left(50 \mathrm{mg} \cdot \mathrm{L}^{-1}\right)$ of molar absorptivity versus wavelength

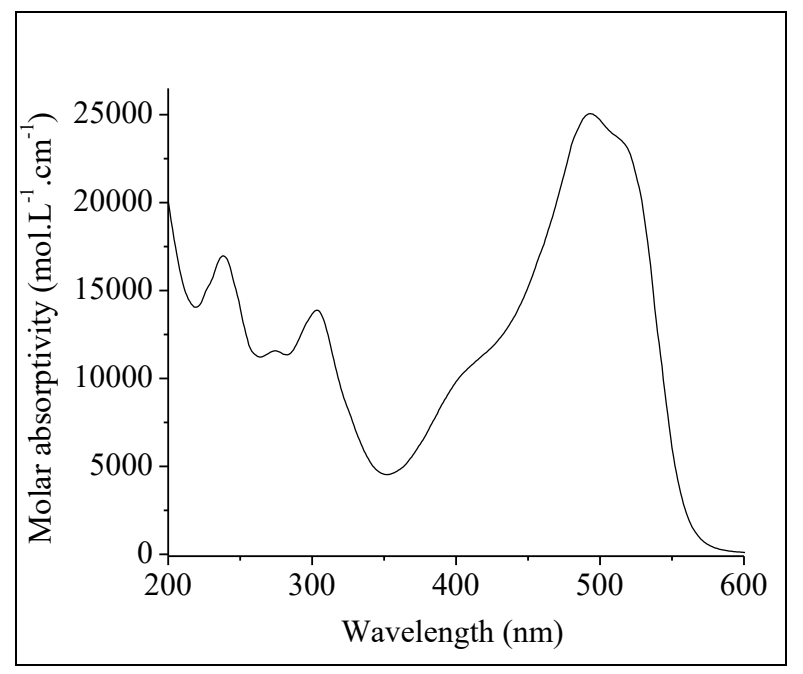

When analyzing Figure 1, three peaks (238, 304 and $495 \mathrm{~nm}$ ) can be detected, in which orange 26 dye degradation monitoring will be performed. According to Catanho et al. (2006), the textile dyes show similar structures and groupings, and according to the work of these researches it can be stated that the DO26 dye presents a chromophore group at $495 \mathrm{~nm}$, whereas for $\lambda=238 \mathrm{~nm}$, the presence of a amine-acetanilide group is verified. With respect to the peak observed at $304 \mathrm{~nm}$, Pinheiro et al. (2004) state that textile dyes present 3 zones of maximum absorbance and this $\lambda$ is in zone II (between 250 and $350 \mathrm{~nm}$ ), where the presence of amines is observed. After the determination of $\lambda$, the treatment using advanced oxidation processes was carried out.

The work solution was submitted to the Fenton and solar photo-Fenton processes. For the latter, the emission of photons in 3 regions was monitored: UV-A/UV-B; UV-C and visible. Thus, it was observed that the emission of photons in the visible region was in the range of 7.13 to $8.99 \mathrm{~W} \cdot \mathrm{cm}^{-2}$, while in UV-A/UV-B region the range was from $1.57 \times 10^{-3}$ to $1.76 \times 10^{-3} \mathrm{~W} \cdot \mathrm{cm}^{-2}$ and in UV-C from 5.0 
observed that the emission of photons in the visible region was in the range of 7.13 to $8.99 \mathrm{~W} \cdot \mathrm{cm}^{-2}$, while in UV-A/UV-B region the range was from $1.57 \times 10^{-3}$ to $1.76 \times 10^{-3} \mathrm{~W} \cdot \mathrm{cm}^{-2}$ and in UV-C from 5.0 $\mathrm{x} 10^{-3}$ to $6.5 \times 10^{-3} \mathrm{~W} \cdot \mathrm{cm}^{-2}$, indicating that in the experiments carried out during the study, visible light had a great contribution.

It is important to emphasize that these two processes were chosen since the previous study carried out by the research group (SANTANA et al., 2017) indicated that the combination between Fenton and photo-Fenton/solar processes present better results than when using isolated from radiation (photolysis). This fact is in agrément with the one obtained by Brito and Silva (2012), who observed that when using the hydrogen peroxide associated with some type of radiation, a more energetic indirect reaction occurs, since the oxidation potential of the hydroxyl radical $\left(\mathrm{E}_{0}=+2,80 \mathrm{~V}\right)$ is higher than that of molecular hydrogen peroxide $\left(\mathrm{E}_{0}=+1,78 \mathrm{~V}\right)$.

It was verified that both processes were efficient in the degradation of the dye DO26, being verified a greater efficiency for the solar photo-Fenton process, as can be observed in Table 2. It is noteworthy that once the experiments were performed in triplicate, the results are expressed considering the mean and standard deviation.

Table 2 - Results (in concentration) of the preliminary study for the Fenton and photo-Fenton processes

\begin{tabular}{c|c|c|c}
\hline \multirow{2}{*}{ Process } & \multicolumn{3}{|c}{ Dye concentration } \\
\cline { 2 - 4 } & $\mathbf{2 3 8} \mathbf{~ n m}$ & $\mathbf{3 0 4} \mathbf{~ n m}$ & $\mathbf{4 9 5} \mathbf{~ n m}$ \\
\hline Initial & $50.40 \mathrm{mg} \cdot \mathrm{L}^{-1}$ & $49.96 \mathrm{mg} \cdot \mathrm{L}^{-1}$ & $49.48 \mathrm{mg} \cdot \mathrm{L}^{-1}$ \\
\hline Fenton & $41.78 \pm 0.60 \mathrm{mg} \cdot \mathrm{L}^{-1}$ & $27.90 \pm 0.28 \mathrm{mg} \cdot \mathrm{L}^{-1}$ & $4.34 \pm 0.13 \mathrm{mg} \cdot \mathrm{L}^{-1}$ \\
\hline Photo-Fenton & $9.62 \pm 0.95 \mathrm{mg} \cdot \mathrm{L}^{-1}$ & $6.71 \pm 0.77 \mathrm{mg} \cdot \mathrm{L}^{-1}$ & $0.54 \pm 0.20 \mathrm{mg} \cdot \mathrm{L}^{-1}$ \\
\hline
\end{tabular}

It was possible to verify that the solar photo-Fenton process reached the following degradation percentages for each of the analyzed wavelengths: 80.92\% (238 nm), 86.57\% (304 nm) and 98.91\% (495 $\mathrm{nm}$ ); while the Fenton reaction (performed without light assistance) reached the following percentages: $17.10 \%$ (238 nm), 44.15\% (304nm) e $91.25(495 \mathrm{~nm})$. It can therefore be inferred that the two types of AOP were able to decrease the initial concentration of DO26 in all their characteristic $\lambda$, and that for the chromophore group, responsible for color, the percentages of degradation were higher than $90 \%$. However, a more detailed study was carried out for both processes and it was found that for the $\lambda$ of $238 \mathrm{~nm}$ only the photo-Fenton process proved to be effective. This analysis is essential, as this wavelength indicates the presence of aromatic hydrocarbons in organic molecules, which are capable of conferring toxicity to polluting substances (PAULINO; ARAÚJO; SALGADO, 2015).

To analyze possible interference of $\mathrm{H}_{2} \mathrm{O}_{2}$ and iron in the analyzes carried out in the UV-Vis spectrophotometer, sweeps were performed in the 200-600 $\mathrm{nm}$ wavelength range, considering the possible interferents (water, water / $\mathrm{H}_{2} \mathrm{O}_{2} / \mathrm{Fe}$ used iron in the form of ferrous sulfate heptahydrate)), as well as the solution containing the dyes and the latter containing the reactants. Therefore, it was verified that the reagents used in the AOP do not interfere with the analyzes performed on the UV-Vis equipment as can be observed in Figure 3. 
Figure 3 - Scanning spectrum for DO26 solution $\left(50 \mathrm{mg} \cdot \mathrm{L}^{-1}\right)$, water, solution of $\mathrm{Fe} / \mathrm{H}_{2} \mathrm{O}_{2}$ and solution containing the dye $\mathrm{DO} 26 / \mathrm{Fe} / \mathrm{H}_{2} \mathrm{O}_{2}$

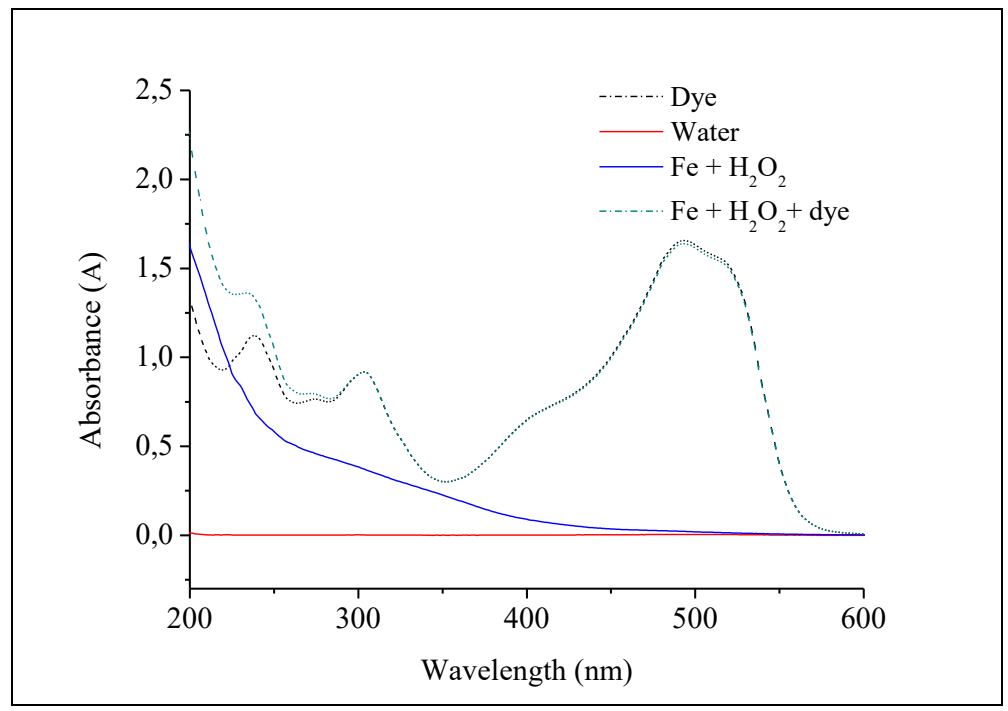

Then it was proceeded to the study of the factorial planning of the Fenton and solar photo-Fenton processes. The main objective was to optimize $\left[\mathrm{H}_{2} \mathrm{O}_{2}\right]$ e $[\mathrm{Fe}]$, as well as the working $\mathrm{pH}$.

\subsection{Determination of the best working condition: factorial design}

At first, to ensure that the initially neutral dye molecule ( $\mathrm{pH} 5.5$ ) does not undergo any kind of dissociation or shift of the wavelength in the UV / Vis spectrum, the working solution was analyzed at different pH: 3, 4, 5 and 6 (values that cover the range of study of the AOP). This evaluation showed that no spectral displacement is observed for the studied dye, indicating that there is no interference of $\mathrm{pH}$ for the present study, as can be observed in Figure 4.

Figure 4 - a) Spectral scanning for dye solution at different $\mathrm{pH}$; b) Spectral scanning for dye solution at different $\mathrm{pH}$ in mono-log graph

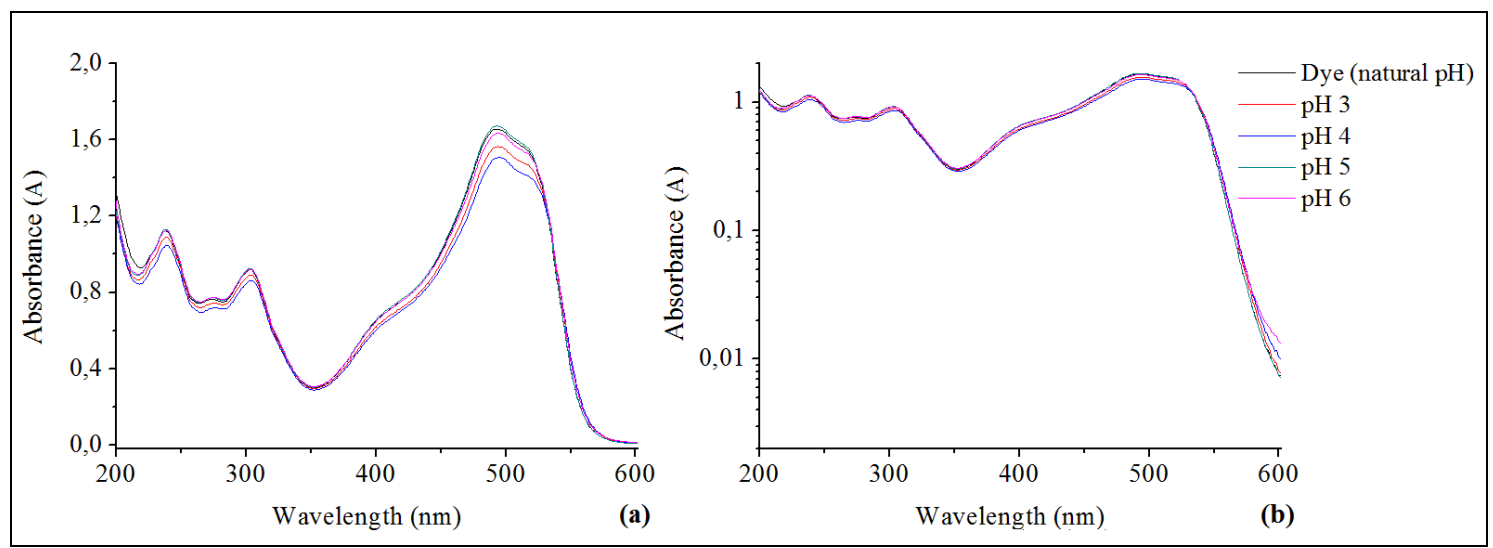


The results with the degradation percentages of the dye under study for the factorial design trials $2^{3}$ with central point (triplicate analysis), for both processes are presented in the Table 3 . It is important to note that for the experiments in which $100 \%$ degradation was verified, peaks in the UV/Vis spectrum were not observed.

Table 3 - Results of the degradation of the dye mixture for the factorial planning $2^{3}$

\begin{tabular}{|c|c|c|c|c|c|c|}
\hline \multirow[t]{2}{*}{ Test } & \multirow{2}{*}{$\begin{array}{l}{\left[\mathrm{H}_{2} \mathrm{O}_{2}\right]} \\
\left(\mathrm{mg} \cdot \mathrm{L}^{-1}\right)\end{array}$} & \multirow{2}{*}{$\begin{array}{c}{[\mathrm{Fe}]} \\
\left(\mathrm{mg} \cdot \mathrm{L}^{-1}\right)\end{array}$} & \multirow[t]{2}{*}{$\mathrm{pH}$} & \multicolumn{3}{|c|}{$\begin{array}{c}\% \text { of degradation } \\
\text { photo-Fenton/Fenton }\end{array}$} \\
\hline & & & & $238 \mathrm{~nm}$ & $304 \mathrm{~nm}$ & $495 \mathrm{~nm}$ \\
\hline 1 & $-1(100)$ & $-1(1)$ & $-1(3-4)$ & $83.7 / 40.8$ & 94.9/59.4 & $100.0 / 92.3$ \\
\hline 2 & $+1(200)$ & $-1(1)$ & $-1(3-4)$ & $74.9 / 31.2$ & $94.5 / 58.5$ & $100.0 / 92.3$ \\
\hline 3 & $-1(100)$ & $+1(5)$ & $-1(3-4)$ & $64.9 / 40.4$ & $79.4 / 73.6$ & 100.0/99.4 \\
\hline 4 & $+1(200)$ & $+1(5)$ & $-1(3-4)$ & $62.5 / 31.9$ & $79.0 / 72.0$ & 100.0/99.2 \\
\hline 5 & $-1(100)$ & $-1(1)$ & $+1(5-6)$ & $84.5 / 0.0$ & $93.1 / 5.0$ & $100.0 / 52.2$ \\
\hline 6 & $+1(200)$ & $-1(1)$ & $+1(5-6)$ & $77.9 / 0.0$ & $93.2 / 9.4$ & $100.0 / 54.7$ \\
\hline 7 & $-1(100)$ & $+1(5)$ & $+1(5-6)$ & $84.1 / 31.7$ & $87.1 / 57.4$ & $99.2 / 93.0$ \\
\hline 8 & $+1(200)$ & $+1(5)$ & $+1(5-6)$ & 73.9/14.6 & $84.0 / 43.4$ & $99.0 / 88.9$ \\
\hline 9 & $0(150)$ & $0(3)$ & $0(4-5)$ & $80.8 / 47.9$ & $89.0 / 78.4$ & $100.0 / 99.4$ \\
\hline 10 & $0(150)$ & $0(3)$ & $0(4-5)$ & $80.8 / 47.9$ & 88.8/78.2 & $100.0 / 99.3$ \\
\hline 11 & $0(150)$ & $0(3)$ & $0(4-5)$ & $80.8 / 48.3$ & $89.0 / 78.3$ & $100.0 / 99.4$ \\
\hline
\end{tabular}

From the analysis of Table 3, it was verified that the experimental conditions for the degradation of DO26 differed when using the different AOP, especially with respect to the amount of ideal iron to be used in the treatment. However, for a better understanding of the results, a statistical analysis was performed. This was based on the calculations of the main effects and interaction between the factors with the aid of the Statistica 6.0 program, to $95 \%$ confidence. Thus, the Pareto charts were constructed for all the characteristic $\lambda$ (Figure 5). 
Figure 5 - Pareto charts for the effects of the variables studied in the Fenton and photo-Fenton/solar processes, in the characteristic $\lambda$ : a) e d) $495 \mathrm{~nm}$; b) e e) $304 \mathrm{~nm}$; c) e f) $238 \mathrm{~nm}$

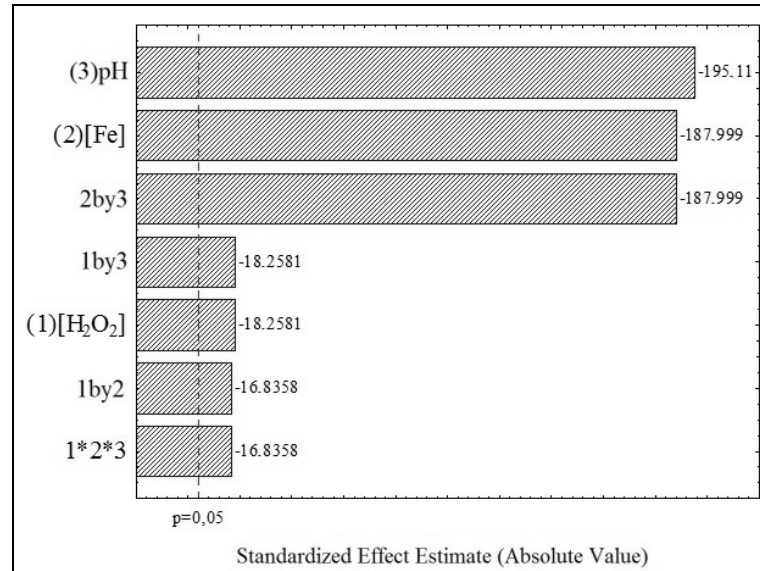

(a)

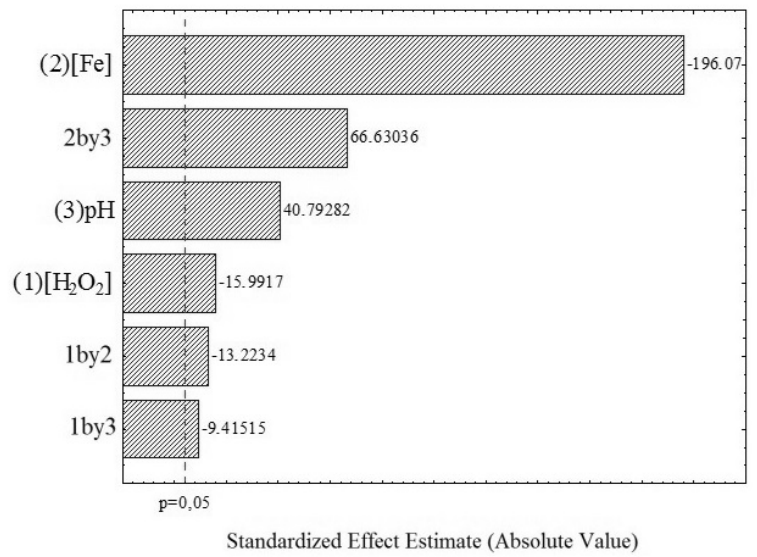

(b)

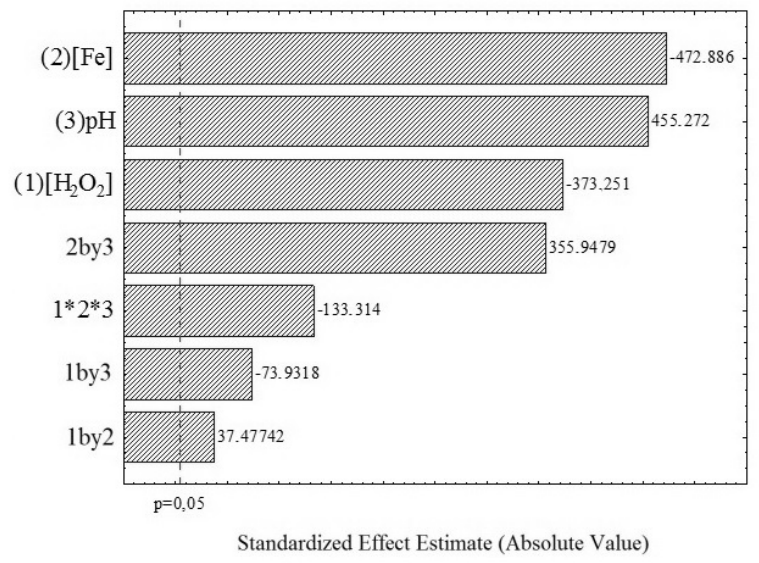

(c)

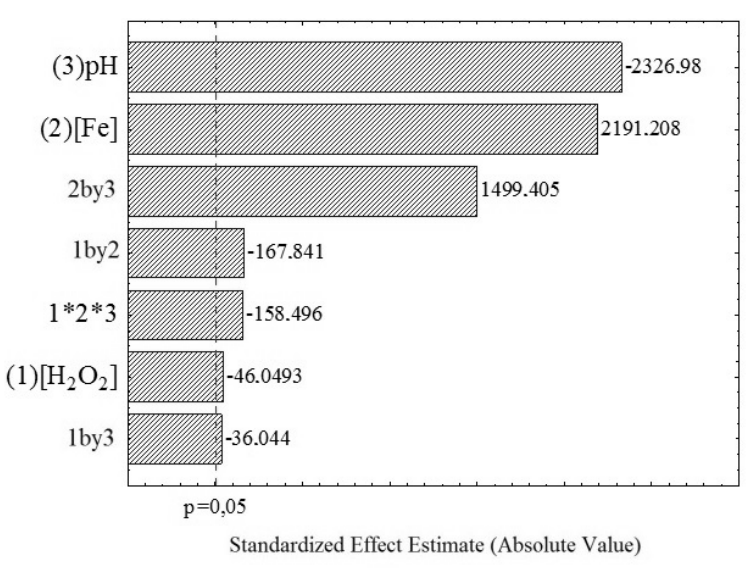

(d)

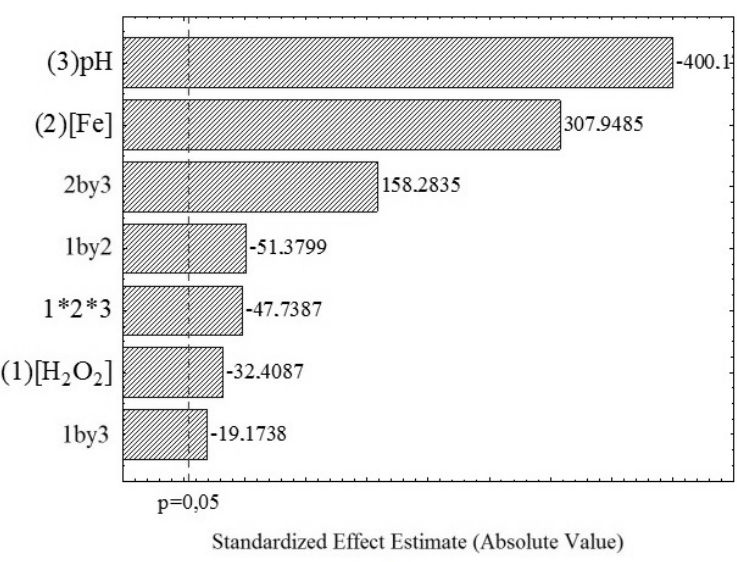

(e)

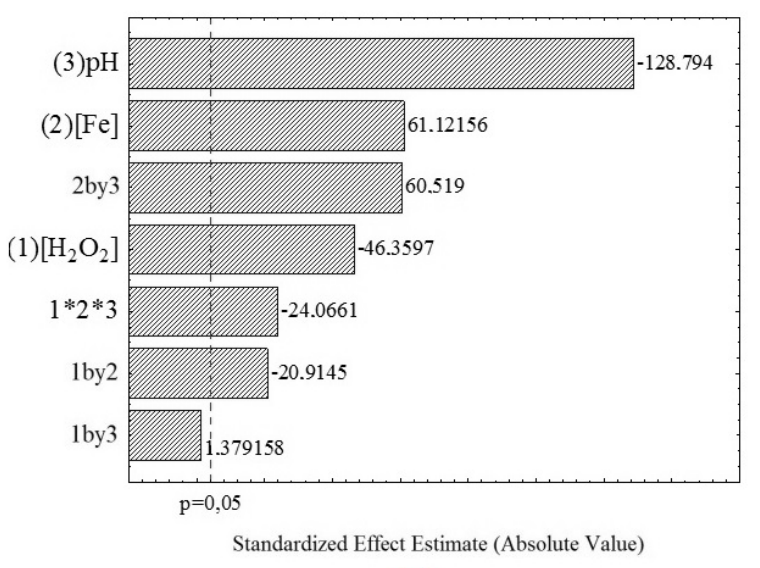

(f)

From the analysis of Figure 5 it is possible to verify that for the solar photo-Fenton process all the main effects and interaction effects were statistically significant at $95 \%$ confidence. As far as the Fenton process is concerned, this one presented a similar behavior, except for the interaction $\left[\mathrm{H}_{2} \mathrm{O}_{2}\right]$ 
and $\mathrm{pH}$, in which no significance was observed. Thus, it can be affirmed that the studied variables cannot be analyzed in isolation, being necessary the generation of the response surfaces (Figures 6 and 7).

Figure 6 - Surface graphs for the wavelengths of: (a), (b) e (c) - $495 \mathrm{~nm}$; (d), (e) e (f) - $304 \mathrm{~nm}$; e (g), (h) e (i) - 238 $\mathrm{nm}$, by employing the solar photo-Fenton process

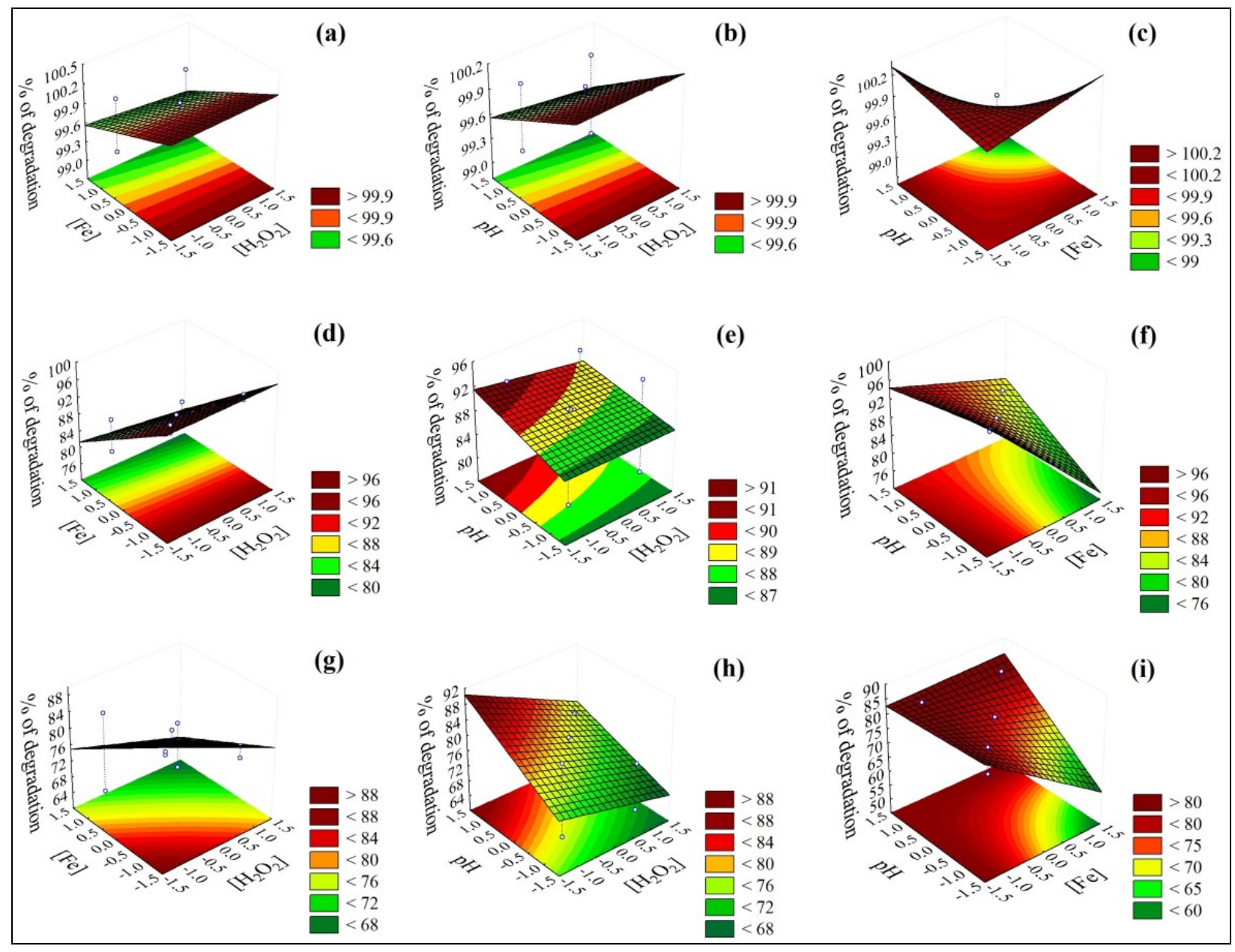

The analysis of Figures $6(\mathrm{a}), 6(\mathrm{~d})$ and $6(\mathrm{~g})$ indicates that the highest percentages of degradation were obtained when $\left[\mathrm{H}_{2} \mathrm{O}_{2}\right]$ e $[\mathrm{Fe}]$ were conjugated at their lowest levels. Regarding the interaction between the factors $\mathrm{pH}$ e $\left[\mathrm{H}_{2} \mathrm{O}_{2}\right]$ (Figures 6(b), 6(e) e 6(h)), it could be seen that for the $\lambda$ of 304 and 238 $\mathrm{nm}$, the highest $\mathrm{pH}$ level would be ideal, however for the $\lambda 495 \mathrm{~nm}$, of the chromophore group, using the lower level of this variable resulted in a better degradation. In this way, the $\mathrm{pH}$ range between 3 and 4 was chosen, since this is considered as the ideal for the photo-Fenton process (FENG et al, (2013)), because in values higher than this range can occur the reduction of hydroxyl radicals from the precipitation of the iron in hydroxide form (BRITO; SILVA, 2012). In addition, it is known that the $\mathrm{H}_{2} \mathrm{O}_{2}$ tends to be unstable in alkaline solution (AŞÇI, 2013). This can be corroborated from the interaction analysis pH-Fe (Figures 6(e), 6(f) e 6(i)), where higher degradation is observed for the lower $\mathrm{pH}$ level used. Therefore, it can be stated that the solar photo-Fenton process presented better results when $\left[\mathrm{H}_{2} \mathrm{O}_{2}\right]=100 \mathrm{mg} \cdot \mathrm{L}^{-1},[\mathrm{Fe}]=1 \mathrm{mg} \cdot \mathrm{L}^{-1}$ and $\mathrm{pH}$ between $3 \mathrm{e} 4$. 
Figure 7 - Response surfaces of the significant interactions of the variables studied for the $\lambda$ of: (a), (b) e (c) 495nm; (d), (e), (f) - 304nm; (g) e (h) - 238nm, when employing the Fenton process

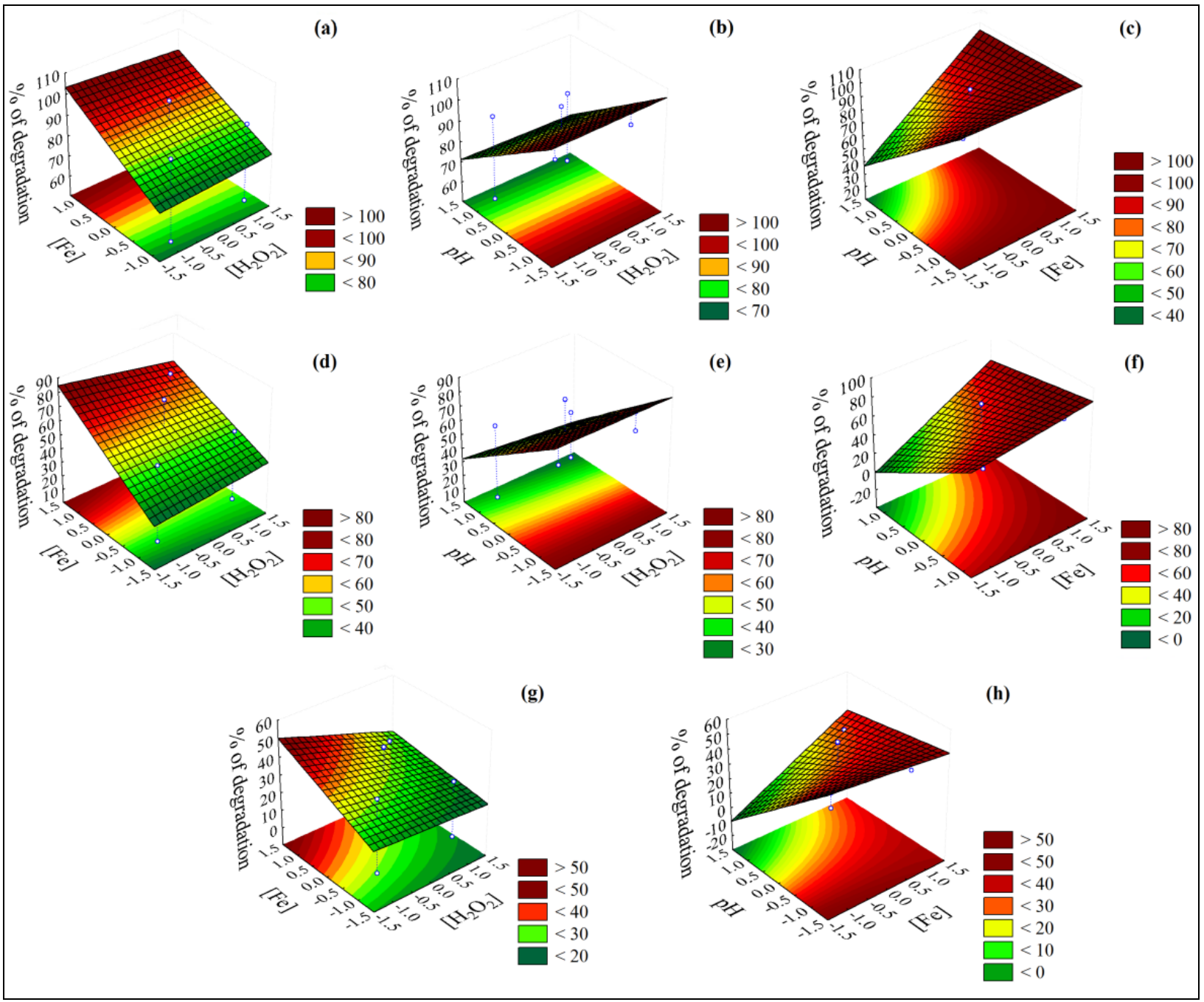

The surface graphics contained in the Figures 7(a) a 7(f) indicate that the chromophoric groups $(\lambda=$ 495 e $304 \mathrm{~nm}$ ) presented similar behaviors for the three interaction effects. Observing them, it was found that a higher efficiency of degradation was achieved when a higher level of [Fe] and a lower $\mathrm{pH}$ range. On the other hand, $\left[\mathrm{H}_{2} \mathrm{O}_{2}\right]$ was not significant and could be fixed at its lowest level, leading to a reduction in costs. These experimental conditions could be corroborated from the response surfaces generated for the $\lambda=238 \mathrm{~nm}$ (Figures $7(\mathrm{~g})$ e $7(\mathrm{~h})$ ). Therefore, it can be stated that the degradation of the studied dyes presented a satisfactory efficiency when using a $\left[\mathrm{H}_{2} \mathrm{O}_{2}\right]$ equal to $100 \mathrm{mg} \cdot \mathrm{L}^{-1}, 5 \mathrm{mg} \cdot \mathrm{L}^{-1}$ of [Fe] and $\mathrm{pH}$ between 3 and 4 . With these conditions, a kinetic monitoring test was carried out for the two processes studied.

\subsection{Kinetic evaluation of the degradation processes}

With the best conditions found, the kinetic study was carried out by monitoring the degradation of the chromophore groups responsible for the coloring, as well as the characteristic groups of the 
aromatic rings, for the two analyzed processes. For this, aliquots were withdrawn at times of $0,25,30$, $35,40,45,50,55,60,65,70,80,90$ and 120 minutes.

Based on the experimental data of the time advance of the dye concentration for each $\lambda$ studied, the kinetic model proposed by Chan and Chu (2003) was used. The kinetic data of the degradation of DO26 for the two oxidative processes applied according to the model are shown in Figure 8.

Figure 8 - Adjustment of the model to the experimental data of the temporal advance of the dye concentration along the oxidation reactions ((a) Fenton process; (b) photo-Fenton process) and degradation and $\mathrm{R}^{2}$ adjustment (c)

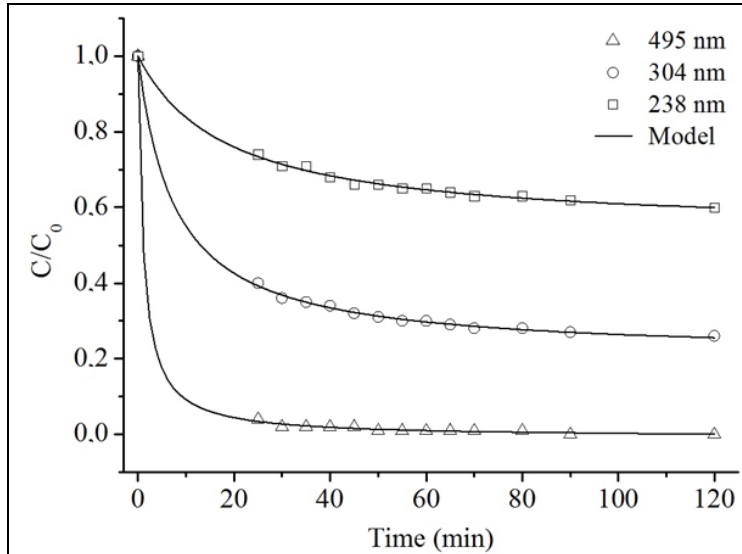

(a)

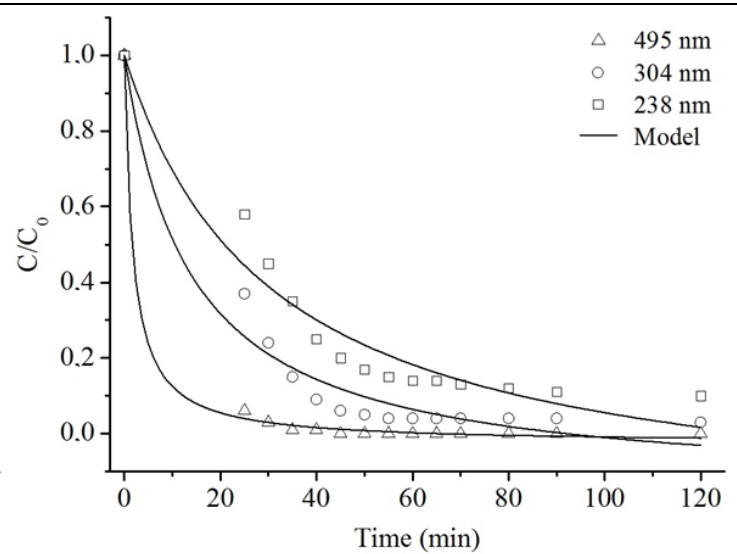

(b)

\begin{tabular}{cccc}
\hline Process & $\boldsymbol{\lambda}(\mathbf{n m})$ & Degradation $(\mathbf{\%})$ & $\mathbf{R}^{\mathbf{2}}$ \\
\hline \multirow{4}{*}{ Fenton } & 495 & 99.71 & 0.999 \\
& 304 & 74.00 & 0.999 \\
& 238 & 40.04 & 0.996 \\
\multirow{5}{*}{ Photo-Fenton } & 495 & 99.98 & 0.999 \\
& 304 & 96.67 & 0.962 \\
& 238 & 90.02 & 0.939 \\
\hline
\end{tabular}

(c)

Through the analysis of Figure 8, it was observed that the proposed model fitted well to the experimental data, obtaining significant linear regression coefficients (greater than 0.9). It was also verified that after $60 \mathrm{~min}$ it was possible to degrade more than $99 \%$ of the chromophore group, observed in $\lambda=495 \mathrm{~nm}$, and a total color removal was also found visually for both processes. A similar result was found by Asçi (2013), which was able to degrade $98 \%$ of DO26 dye after the same time period using heterogeneous Fenton process. Among the treatments, the photo-Fenton process assisted by solar radiation was more efficient, which was already expected, due to its photolytic capacity.

The higher efficiency of radiation-assisted processes has been reported by Santana et al (2017), who studied the degradation of textile dyes by homogeneous Fenton processes. According to literature, this efficiency is related to the fact that radiation does not only act as a source of photons, but also as a source of heat, which results in an increase in the activity of the system (SOUZA; PERALTAZAMORA; ZAWADZKI, 2008). 
In addition, the kinetic modeling proposed by the nonlinear model allowed us to calculate the main parameters for each treatment process investigated. In Table 4 the kinetic data derived from the application of the suggested model are arranged.

Table 4 - Kinetic parameters for DO26 modeling

\begin{tabular}{c|c|c|c|c}
\hline \multirow{2}{*}{$\lambda(\mathbf{n m})$} & \multicolumn{2}{|c|}{ Fenton } & \multicolumn{2}{c}{ photo-Fenton } \\
\cline { 2 - 5 } & $\mathbf{1 / Q}\left(\mathbf{m i n}^{-1}\right)$ & $\mathbf{1 / \sigma}$ & $\mathbf{1 / Q}\left(\mathbf{m i n}^{-1}\right)$ & $\mathbf{1 / \sigma}$ \\
\hline $\mathbf{4 9 5}$ & 0.917 & 1.010 & 0.599 & 1.031 \\
\hline $\mathbf{3 0 4}$ & 0.104 & 0.794 & 0.084 & 1.149 \\
\hline $\mathbf{2 3 8}$ & 0.025 & 0.463 & 0.040 & 1.235 \\
\hline
\end{tabular}

According to Paulino; Araújo and Salgado (2015), the greater the reason $1 / \rho$, the higher the dye concentration will be. In this sense, it was observed, through analysis of Table 4 , that the reaction kinetics was more favorable for the Fenton process, in the $\lambda$ responsible for the coloration conference. However, it was found that it did not differ significantly from the solar photo-Fenton process, and that this presented better result for the $\lambda$ of the aromatic groups. The ratio $1 / \sigma$, according to the same authors, is equivalent to the maximum oxidation capacity at the end of the process. Thus, the data in Table 4 show that although the dye under study, in its $\lambda$ characteristic, had a degradation efficiency analogous to the end of the treatment when using the two Fenton reactions, the process assisted by radiation had a greater oxidative capacity.

To guarantee that the Fenton and solar photo-Fenton processes were efficient, as well as to evaluate the appearance of possible reaction intermediates, a qualitative scanning analysis between 200 and $600 \mathrm{~nm}$ was carried out on UV-Vis equipment. This spectral analysis to monitor the absorption profile of the degradation of the dye solution occurred under the same conditions of the kinetic study at the times of 25, 45, 90 and 120 min. The spectra obtained are shown in Figure 9.

Figure 9 - (a) Spectral monitoring of DO26 dye degradation; (b) Spectral monitoring of DO26 dye degradation in mono-log graph

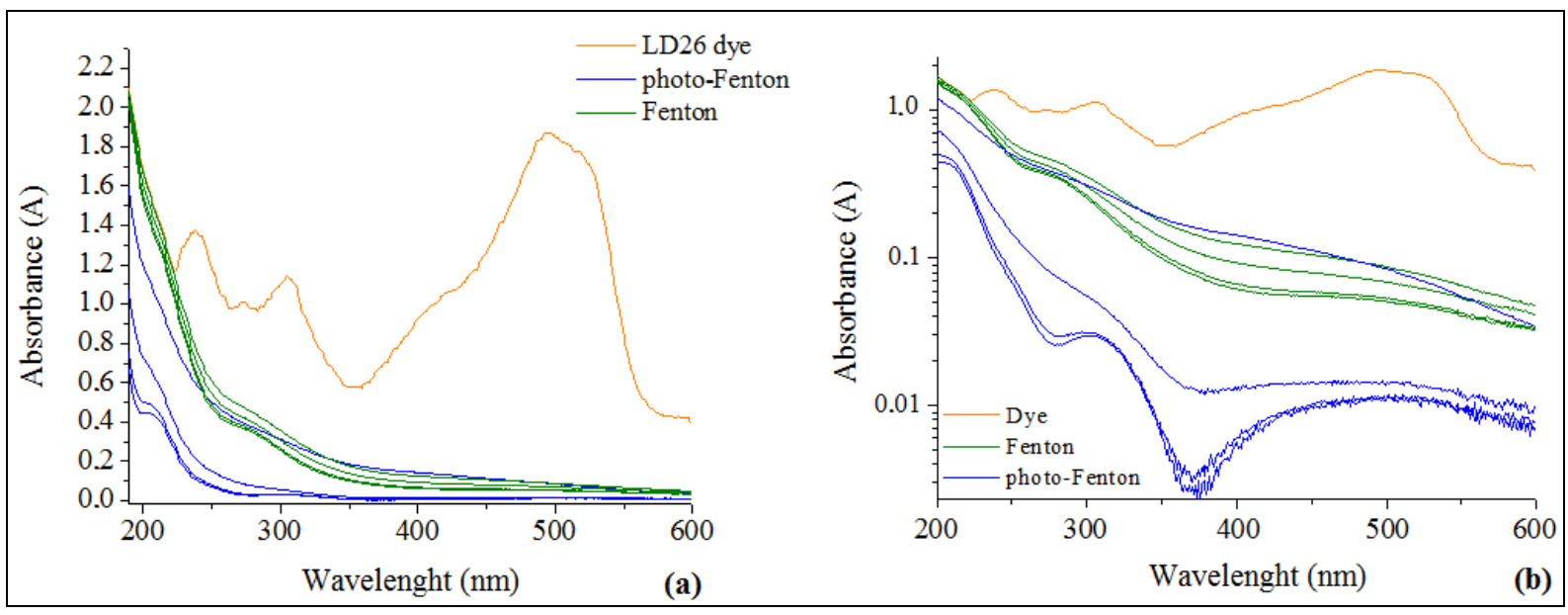


It is possible to observe a reduction in the intensity of the peaks identified at the initial time, as well as the absence of reaction intermediates in the wavelength range, indicating the efficiency of the processes used. This assertion is possible, since the formation of another peak during the degradation process was not verified, thus showing its efficiency as observed in the quantitative analysis performed through the kinetic study. In this context, a study on the concentrations of organic matter was carried out to better analyze the efficiency of the degradation process.

\subsection{Behavior of chemical oxygen demand}

To ensure that, in addition to the total color removal and degradation of the characteristic groups of the dye, also the organic matter reduction occurred, the chemical oxygen demand (COD) analysis of the solution containing the DO26 before and after treatment for the two processes proposed. Since the presence of $\mathrm{H}_{2} \mathrm{O}_{2}$ exerts a direct influence on the determination of $\mathrm{COD}$, and that the remaining amount of this reagent can consume the $\mathrm{K}_{2} \mathrm{Cr}_{2} \mathrm{O}_{7}$ used in this type of analysis (TALINLI; ANDERSON, 1992), an evaluation of the residual concentration of hydrogen peroxide was carried out using a colorimetric method with MQuant Test Strips (Merck), with $\mathrm{H}_{2} \mathrm{O}_{2}$ ranging from 0 to $25 \mathrm{mg} \cdot \mathrm{L}^{-1}$.

It was found that after 120 minutes a residual $\mathrm{H}_{2} \mathrm{O}_{2}$ concentration existed between 5 and $10 \mathrm{mg} \cdot \mathrm{L}^{-1}$ for the Fenton process and between 2 and $5 \mathrm{mg} \cdot \mathrm{L}^{-1}$ for the solar photo-Fenton process. Once the presence of about 10 and $5 \%$ of the initial $\mathrm{H}_{2} \mathrm{O}_{2}$ used in the respective processes has been verified, which can affect the determination of COD by overestimating its value, and to obtain reliable results, COD measurements of peroxide solutions of hydrogen with concentration of $1 \mathrm{~g} \cdot \mathrm{L}^{-1}$. The mean value obtained between the analyzes was $0.41 \mathrm{mg} \mathrm{COD}$ per $\mathrm{mg} \mathrm{H}_{2} \mathrm{O}_{2}$. In a study carried out by Lee et al (2011) it was estimated a COD of $0.52 \mathrm{mg}$ per $\mathrm{mg}$ of $\mathrm{H}_{2} \mathrm{O}_{2}$, while Chavoshani et al (2016) obtained in their work a value equal to $0.49 \mathrm{mg}$ of $\mathrm{COD}$ per $\mathrm{mg}$ of $\mathrm{H}_{2} \mathrm{O}_{2}$.

The COD value for the pre-treatment solution was $47.81 \mathrm{mg} \cdot \mathrm{L}^{-1}$. Considering the correction of the amount of $\mathrm{H}_{2} \mathrm{O}_{2}$, it was possible to obtain a mean organic matter $62.05 \%$ for the Fenton process, and $66.41 \%$ for the photo-Fenton process. It can be inferred from these results that the conversion of the organic matter does not occur in the same way as the decrease of the color, since although there is a destruction of the chromophoric groups, there is formation (although in low concentrations) of intermediate products; making a not so good COD reduction happen (SU et al, 2011; MARTÍNEZHUITLE; BRILLAS, 2009).

From this study, it can be observed that the alternation between the solar photo-Fenton process (for the period of exposure to solar radiation) and Fenton (nocturnal period - where there is no incidence of solar radiation) is feasible in treatment plants laundries and textile industries. Thus, it can be ensured that good levels of degradation of the dyes will be obtained, as well as conversion of COD, which favors the application of the operational conditions.

\subsection{Toxicity Study: evaluation against seeds and bacteria}

The toxicity analyzes using seeds and bacteria were performed with the untreated dye solution and after submission to the Fenton and solar photo-Fenton processes under the same conditions described for the kinetic study.

The results of toxicity using seeds showed that the species studied (Lactuca Sativa, Cichorium intybus, Brassica juncea and Portulaca grandiflora) were able to settle in dye solution medium before and 
after AOP. However, it was found that these solutions did not behave similarly to the negative control, which caused lethal and sublethal effects on the seeds. This fact can be verified from the analysis of Table 5, in which the germination index (GI) and relative growth rate (RGR) are listed.

Table 5 - GI(\%) and RGR values for the seeds of Lactuca Sativa, Cichorium intybus, Brassica juncea and Portulaca grandiflora (triplicate analysis)

\begin{tabular}{c|c|c|c|c|c|c|c|c}
\hline \multirow{2}{*}{ Sample } & \multicolumn{2}{|c|}{ Lactuca sativa } & \multicolumn{2}{c|}{ Cichorium intybus } & \multicolumn{2}{c|}{ Brassica juncea } & \multicolumn{2}{c}{$\begin{array}{c}\text { Portulaca } \\
\text { grandiflora }\end{array}$} \\
\cline { 2 - 9 } & GI(\%) & RGR & GI(\%) & RGR & GI(\%) & RGR & GI(\%) & RGR \\
\hline Water & 100.00 & 1.00 & 100.00 & 1.00 & 100.00 & 1.00 & 100.00 & 1.00 \\
\hline SBT $^{*}$ & 29.91 & 0.45 & 73.71 & 0.87 & 45.78 & 0.73 & 55.24 & 0.76 \\
\hline Fenton & 44.98 & 0.64 & 77.87 & 0.92 & 66.21 & 0.74 & 59.67 & 0.77 \\
\hline $\begin{array}{c}\text { Photo- } \\
\text { Fenton }\end{array}$ & 38.53 & 0.61 & 78.91 & 0.93 & 78.12 & 0.81 & 80.55 & 0.89 \\
\hline
\end{tabular}

*SBT $=$ Solution before treatment

According to the results shown in Table 5, it was verified that the solution after treatment presented the best germination and relative growth rate with respect to the initial solution. In addition, it was observed that there was no significant difference in the growth of the seed radicles for the analyzed processes (Fenton and photo-Fenton). According to Young et al (2012) it can be affirmed that there is an inhibition of the growth when the values of the RGR are inferior to 0.80 . Thus, even after the Fenton process, the dye solution still caused a delay in the development of the species of Lactuca sativa, Brassica juncea and Portulaca grandiflora. This fact can also be observed for the photoFenton process compared to the Lactuca sativa species; making it necessary to carry out more detailed studies. Thus, considering another type of biota, the toxicity to bacteria was evaluated.

To determine the bacterial activity of the solutions, tests were carried out in which the optical densities at $600 \mathrm{~nm}\left(\mathrm{OD}_{600}\right)$ of each sample were evaluated for the bacteria Escherichia coli and Proteus mirabilis. The results of the mean and standard deviation $(\sigma)$ of each test for OD600 between the initial time and after 24 hours are presented in Table 6.

Table 6 - Results of toxicity tests for bacteria Escherichia coli and Proteus mirabilis

\begin{tabular}{|c|c|c|}
\hline \multirow{2}{*}{ Sample } & Escherichia coli & Proteus mirabilis \\
\hline & \multicolumn{2}{|c|}{ Mean $\pm \sigma\left(\mathrm{OD}_{600}\right)$} \\
\hline Water (control) & $0.202 \pm 0.001$ & $0.410 \pm 0.003$ \\
\hline SBT $^{*}$ & $0.264 \pm 0.016$ & $0.384 \pm 0.003$ \\
\hline Fenton & $0.302 \pm 0.023$ & $0.460 \pm 0.070$ \\
\hline Photo-Fenton & $0.232 \pm 0.003$ & $0.395 \pm 0.037$ \\
\hline
\end{tabular}

*SBT $=$ Solution before treatment

The analysis of Table 6 shows that, based on the OD 600 values, the bacterial growth of E. coli strains presented values higher than the control, both for the solutions before the treatment and for the 
solutions after the AOP used, indicating that there was no inhibition of this bacterium. However, there was a small inhibition of the P. mirabilis strains for the UDS samples (6.2\%) and after the solar photoFenton process $(3.6 \%)$, which may be inside of experimental error. In general terms it can be affirmed that the samples analyzed before and after the treatment did not present toxicity for the bacterial species studied.

\section{CONCLUSION}

Fenton and photo-Fenton processes were efficient in the degradation of dye DO26 in aqueous solution. The photo-Fenton process assisted by natural solar radiation presented better performance when using $\left[\mathrm{H}_{2} \mathrm{O}_{2}\right]$ e $[\mathrm{Fe}]$ de $100 \mathrm{e} 1 \mathrm{mg} \cdot \mathrm{L}^{-1}$, respectively; besides adjusting the $\mathrm{pH}$ of the solution to a range between 3-4. Under these conditions, the process led to $100 \%$ degradation of OD26 after 120 min. The best experimental conditions for the Fenton process were $\left[\mathrm{H}_{2} \mathrm{O}_{2}\right]=100 \mathrm{mg} \cdot \mathrm{L}^{-1},[\mathrm{Fe}]=5 \mathrm{mg} \cdot \mathrm{L}^{-1}$ and the same $\mathrm{pH}$ range, and this showed efficiency of $99.46 \%$. Both processes presented a good fit for the kinetics of nonlinear degradation described by Chan and Chu. As far as toxicity is concerned, it was found that for Lactuca sativa, Brassica juncea e Portulaca grandiflora there was a growth retardation when employing the Fenton process; while the photo-Fenton process only influenced the decrease of the RGR of the seeds of Lactuca sativa. As for the toxicological tests against the bacteria Escherichia coli and Proteus mirabilis the processes employed did not interfere in the development of the strains used.

\section{ACKNOWLEDGEMENTS}

For NUQAAPE/FACEPE, FADE/UFPE and CAPES.

\section{REFERENCES}

ABIT. Associação Brasileira da Indústria Têxtil e de Confecção. Perfil do setor. Disponível em: $<$ http://www.abit.org.br/cont/perfil-do-setor>. Acesso em: 28 nov. 2017.

APHA: AMERICAN PUBLIC HEALTH ASSOCIATION. Standard Methods for The Examination of Water and Wastewater. 22 ed. Washington: APHA, 2012.

AŞÇI, Y. Decolorization of Direct Orange 26 by heterogeneous Fenton oxidation. Desalination and Water Treatment, v. 51, n. 40-42, p. 7612-7620, 2013.

BANASCHIKA, R.; JABLONOWSKI, H.; BEDNARSKI, P. J.; KOLBA J. F., Degradation and intermediates of diclofenac as instructive example for decomposition of recalcitrant pharmaceuticals by hydroxyl radicals generated with pulsed corona plasma in water. Journal of Hazardous Materials, v. 342, p. 651-660, 2018.

BILINSKA, L.; GMUREK, M.; LEDAKOWICZ S. Textile wastewater treatment by AOPs for brine reuse. Process Safety and Environmental Protection, v. 109, p. 420-428, 2017.

BRINDHA, R.; MUTHUSELVAM, P.; SENTHILKUMAR, S.; RAJAGURU P. Fe ${ }^{0}$ catalyzed photoFenton process to detoxify the biodegraded products of azo dye Mordant Yellow 10. Chemosphere, v. 201, p. 77-95, 2018. 
BRITO, N. N. D.; SILVA, V. B. M. Processos oxidativos avançados e sua aplicação ambiental. Revista Eletrônica de Engenharia Civil, v. 1, n. 3, p. 36-47, 2012.

CATANHO, M.; MALPASS, G. R. P.; MOTHEO, A. J. Avaliação dos tratamentos eletroquímico e fotoeletroquímico na degradação de Corantes têxteis. Química Nova, v. 29, n. 5, p. 983-989, 2006.

CHAKMA, S.; DAS, L. MOHOLKAR, V. S. Dye decolorization with hybrid advanced oxidation processes comprising sonolysis/Fenton-like/photo-ferrioxalate systems: A mechanistic investigation. Separation and Purification Technology, v. 156, n. 1, p. 596-607, 2015.

CHAN, K. H.; CHU, W. Modeling the reaction kinetics of Fenton's process on the removal of atrazine. Chemosphere, v. 51, n. 4, p. 305-311, 2003.

CHAVOSHANI, A.; ROSTAMI, A.; GOLZARI, F.; GHOLINIA, A. The Effect of $\mathrm{H}_{2} \mathrm{O}_{2}$ Interference in Chemical Oxygen Demand Removal During Advanced Oxidation Processes. Iranian Journal of Health, Safety and Environment, v. 3, n. 3, p. 565-569, 2016.

DÜKKANCI M. Sono-photo-Fenton oxidation of bisphenol-A over a $\mathrm{LaFeO}_{3}$ perovskite catalyst. Ultrasonics. Sonochemistry, v. 40, p. 110-116, 2018.

FENG, L.; HULLEBUSCH, E. D. V.; RODRIGO, M. A.; ESPOSITO, G.; OTURAN, M. A. Removal of residual anti-inflammatory and analgesic pharmaceuticals from aqueous systems by electrochemical advanced oxidation processes: A review. Chemical Engineering Journal, v. 228, p. 944-964, 2013.

HASANBEIGI, A.; HASANABADI, A.; ABDORRAZAGHI, M. Comparison analysis of energy intensity for five major sub-sectors of the Textile Industry in Iran. Journal of Cleaner Production, v. 23, n. 1, p. 186-194, 2012.

HERNÁNDEZ-FRANCISCOA， E.; PERAL， J.; BLANCO-JEREZ, L. M. Removal of phenolic compounds from oil refinery wastewater by electrocoagulation and Fenton/photo-Fenton processes. Journal of Water Process Engineering, v. 19, p. 96-100, 2017.

Instituto Nacional de Metrologia, Normalização e Qualidade Industrial (INMETRO). DOQ-CGCRE008: Orientações sobre Validação de Métodos Analíticos. Rev. 04, 2011. 20 p.

LABIADHA, L.; OTURANB, M. A.; PANIZZAC, M.; HAMADI, N. B.; AMMAR, S. Complete removal of AHPS synthetic dye from water using new electro-fenton oxidation catalyzed by natural pyrite as heterogeneous catalyst. Journal of Hazardous Materials, v. 297, p. 34-41, 2015.

LEE, E.; LEE, H.; KIM, Y. K.; SOHN, K.; LEE, K. Hydrogen peroxide interference in chemical oxygen demand during ozone based advanced oxidation of anaerobically digested livestock wastewater. International Journal of Environmental Science \& Technology, v. 8, n. 2, p. 381-88, 2011. 
MARTÍNEZ-HUITLE C. A.; BRILLAS, E. Decontamination of wastewaters containing synthetic organic dyes by electrochemical methods: A general review. Applied Catalysis B: Environmental, v. 87, n. 3-4, p. 105-145, 2009.

MARTINS, L. M.; SILVA, C. E.; MOITA NETO, J. M.; LIMA, A. S.; MOREIRA, R. F. P. M. Aplicação de Fenton, foto-Fenton e $\mathrm{UV} / \mathrm{H}_{2} \mathrm{O}_{2}$ no tratamento de efluente têxtil sintético contendo o corante Preto Biozol UC. Engenharia Ambiental e Sanitária, v. 16, n. 3, p. 261-270, 2011.

NAGEL-HASSEMER, M. E.; CORAL, L. A.; LAPOLLI, F. R; AMORIM, M. T. S. P. Processo UV/ $\mathrm{H}_{2} \mathrm{O}_{2}$ como pós-tratamento para remoção de cor e polimento final em efluentes têxteis. Química Nova, v. 35, n. 5, p. 900-904, 2012.

NAPOLEÃO, D. C.; ZAIDAN, L. E. M. C.; DIAZ, J. M. R.; SANTANA, R. M. R.; MONTENEGRO, M. C. B.; ARAUJO, A. N.; BENACHOUR, M.; SILVA, V. L. Use of the photo-Fenton process to discover the degradation of drugs present in water from the Wastewater Treatment Plants of the pharmaceutical industry. Afinidad, v. 75, p. 19-27, 2018.

PAULINO, T. R. S.; ARAÚJO, R. S.; SALGADO, B. C. B. Estudo de oxidação avançada de corantes básicos via reação Fenton $\left(\mathrm{Fe} 2+/ \mathrm{H}_{2} \mathrm{O}_{2}\right)$. Engenharia Sanitária e Ambiental, v. 20, n. 3, p. 347-352, 2015.

PEREIRA, E. B.; MARTINS, F. R.; GONÇALVES, A. R.; COSTA, R. S.; LIMA, F. J. L.; RUTHER, R.; ABREU, S. L.; TIEPOLO, G. M.; PEREIRA, S. V.; SOUZA, J. F. Atlas Brasileiro de Energia Solar (ebook), INPE, 2ed, 2017, 88p.

PINHEIRO, H. M.; TOURAUD, E.; THOMAS, E. Aromatic amines from azo dye reduction: status review with emphasis on direct UV spectrophotometric detection in textile industry wastewaters. Dyes and Pigments, v. 61, p. 121-139, 2004.

PUNZI M.; ANBALAGAN A.; BÖRNER R. A.; SVENSSON B.; JONSTRUP M., MATTIASSON B. Degradation of a textile azo dye using biological treatment followed by photo-Fenton oxidation: Evaluation of toxicity and microbial community structure. Chemical Engineering Journal, v. 270, p. 290-299, 2015.

SAFA, Y.; BHATTI, H. N. Kinetic and thermodynamic modeling for the removal of Direct Red-31 and Direct Orange-26 dyes from aqueous solutions by rice husk. Desalination, v. 272, n. 1-3, p. 313-322, 2011.

SALVADOR, T.; MARCOLINO JR, L. H.; PERALTA-ZAMORA. Degradação de corantes têxteis e remediação de resíduos de tingimento por processo de Fenton, foto-Fenton e eletro-Fenton. Química Nova, v. 35, n. 5, p. 932-938, 2012.

SANTANA, R. M. R.; NASCIMENTO, G. E.; NAPOLEÃO, D. C.; DUARTE, M. M. M. B. Degradation and kinetic study of Reactive blue BF-5G and Remazol red RB 133\% dyes using Fenton and photoFenton process. Electronic Journal of Management, Education and Environmental Technology (REGET), v. 31, n. 2, p. 104-118, 2017. 
SOUZA, K. V.; PERALTA-ZAMORA, P.; ZAWADZKI, S. F. Imobilização de ferro (II) em matriz de alginato e sua utilização na degradação de corantes têxteis por processos Fenton. Química Nova, v. 31, n. 5, p. 1145-1149, 2008.

SU, C.; PUKDEE-ASA, M.; RATANATAMSKUL, C.; LU, M. Effect of operating parameters on decolorization and COD removal of three reactive dyes by Fenton's reagent using fluidized-bed reactor. Desalination, v. 278, p. 211-218, 2011.

TALINLI, I.; ANDERSON, G. K. Interference of hydrogen peroxide on the standard COD test. Water research, v. 26, n. 1, p. 107-110, 1992.

YONGZE, L.; HAOWAN S.; LIQIU, Z.; LI F. Photodegradation behaviors of 17-estradiol in different water matrixes. Process Safety and Environmental Protection, v. 112, p. 335-341, 2017.

YOUNG, B. J.; RIERA, N. I.; BEILY, M. E.; BRES, P. A.; CRESPO, D. C.; RONCO, A. E. Toxicity of the effluent from an anaerobic bioreactor treating cereal residues on Lactuca sativa. Ecotoxicology and Environmental Safety, v. 76, n. 2, p. 182-186, 2012.

ZAGATTO, P. A.; BERTOLETTI, E. Ecotoxicologia Aquática - Princípios e Aplicações. 1. ed. São Carlos: RiMa, 2006. 478 p. 